\title{
Лікування рухом, індукованим обмеженням, у реабілітації хворих з наслідками ішемічного інсульту
}

\author{
Богдановська Н. В., Кальонова І. В. \\ Запорізький національний університет, м. Запоріжжя, Україна
}

Актуальність. На сьогодні рання комплексна нейрореабілітація визнана невід'ємним елементом надання медичної допомоги пацієнтам, які перенесли інсульт, здатним зменшити тяжкість його наслідків. Результати досліджень демонструють можливість стимуляції пластичності мозку терапією вимушеними рухами (Constraint-Induced Movement Therapy - CIMT), що проявляється збільшенням кіркового представництва кисті, ступінь якого корелює з поліпшенням функції руки.

Мета дослідження - вивчення ефективності методики фізичної терапії вимушеними рухами в реабілітації хворих з постінсультними порушеннями рухової функції верхньої кінцівки.

Матеріали та методи. У рамках дослідження нами була застосована терапія рухом, індукованим обмеженням, у 38 хворих у пізньому відновлювальному періоді мозкового інсульту. Групу контролю склали 34 особи; групи були зіставні за статевими, віковими характеристиками, ступенем геміпарезу, давністю інсульту тощо (середній вік хворих склав $63,2 \pm 4,8$ роки). Критеріями включення в основну групу за характером порушення рухової функції були можливість активного розгинання зап'ястя не менше 20 градусів, суглобів кисті - 10 градусів. Оцінку функціональної активності верхньої кінцівки проводили за шкалою Фугл-Мейєра (Fugl-Meyer Assessment of Physical Performance, FMA). Повторне обстеження хворих обох груп проводилось через 4 тижні реабілітації, протягом яких в основній групі застосовувалась методика CIMT тривалістю не менше 4-х годин на день.

Результати дослідження та їх обговорення. Первинне обстеження пацієнтів показало, що вобох групах виявлено ознаки порушення рухової функції верхньої кінцівки за всіма доменами шкали FMA: загальний бал в основній групі склав 39,44 \pm 4,37 бала при оптимальному значенні 64 бали, в контрольній $-37,55 \pm 3,51$ бали. При повторному обстеженні зафіксовано покращення показників рухової функції верхньої кінцівки за доменом “плече - передпліччя" 26,44 $\pm 1,11 \%$ $\mathrm{i} 21,96 \pm 2,72 \%$ ( $<<0,05)$, за доменом "зап'ястя" $-8,18 \pm 0,11 \%$ i $7,21 \pm 0,38 \%(p<0,05)$, за доменом “кисть” - $11,17 \pm 0,42 \%$ i $9,53 \pm 0,31 \%(p<0,05)$ в основній та контрольній групах відповідно.

Висновки. Застосування в реабілітації хворих 3 легкими й помірними парезами руки постінсультного генезу методики кінезотерапії з обмеженням функції неушкодженої кінцівки сприяє кращому відновленню рухової функції паретичної руки.

Перспективи подальших досліджень подальше вивчення застосування методики СІМТ для відновлення рухової функції при синдромі центрального геміпарезу.

Ключові слова: постінсультний парез, вимушені рухи, шкала Fugl-Meyer.

Конфлікт інтересів. Автори декларують відсутність явних і потенційних конфліктів інтересів, пов'язаних з публікацією тез. 